\title{
Okul öncesi rehberlik hizmetlerinin değerlendirilmesi*
}

\author{
The evaluation of preschool guidance services
}

\author{
Makale Geçmişi \\ Geliş : 14 Ağustos 2020 \\ Düzeltme : 2 May1s 2021 \\ Kabul : 19 Mayis 2021
}

\section{Makale Türü}

Araștırma Makalesi

\section{Article History}

Received : 14 August 2020

Revised : 2 May 2021

Accepted : 19 May 2021

\section{Article Type}

Research Article

\author{
Hasan Dilek ${ }^{1}$, Ertuğrul Talu ${ }^{2}$
}

Öz: Okul öncesi eğitim, çocuğun gelişiminde oldukça önemli bir eğitim basamağıdır. Bu dönemde verilecek rehberlik hizmetlerinin temel amacı çocuğun bütünsel gelişimine katkı sağlamaktır. Güncel okul öncesi eğitim programında rehberlik hizmetlerinden bahsedilmiş olması bu yaş aralığındaki rehberlik hizmetlerinin önemini vurgulamaktadır. Bu araştırmada, okul öncesi dönem rehberlik hizmetlerinin paydaş görüşlerine göre değerlendirilmesi amaçlanmıştır. Katılımcılar rehber öğretmenler, okul öncesi öğretmenleri ve ebeveynlerin yer aldığı üç gruptan oluşmaktadır. Araştırmanın veri toplama ve analiz süreci nitel araştırma deseni basamaklarına göre yapılandırılmıştır. Elde edilen bulgulara göre, rehberlik hizmetlerinin okul öncesi eğitimde önemli olduğu, çeşitli problemlerle karşılaşıldığı ve daha da yaygınlaştırılması gerektiği anlaşılmıştır. Araştırma sonuçları doğrultusunda hem alan uygulamalarına hem de yapılacak araştırmalarla ilgili çeşitli öneriler sunulmuştur.

Anahtar Kelimeler: Okul öncesi eğitim, Okul öncesi rehberlik hizmetleri, Okul öncesi rehberlik paydaşları

\begin{abstract}
Preschool education is an important educational level in the development of the child. The main purpose of preschool guidance services is to contribute to the overall development of the child. The guidance services mentioned in the current preschool education program emphasizes the importance of the guidance services in this age range. In this study, it is aimed to evaluate the preschool guidance services according to the opinions of the stakeholders. Participants consist of three groups of counselors, preschool teachers, and parents. The data collection and analysis process of the research is structured according to the qualitative research design steps. According to the findings, it was understood that guidance services are important in pre-school education, various problems are encountered and it should be expanded. In line with the results of the research, various suggestions were presented regarding both field practices and researches to be conducted.
\end{abstract}

Keywords: Preschool education, Preschool guidance services, Preschool guidance stakeholders 


\section{SUMMARY}

\section{Introduction}

The preschool curriculum is one of the elements that improve the quality of preschool education. The curriculum enables teachers to identify educational priorities and to reflect the needs of stakeholders, particularly children who are important for pre-school education. The expressions regarding guidance in the characteristics of the curriculum that are applied in preschool education institutions in Turkey have made the guidance services in preschool education a remarkable subject. The purpose of the guidance services to be provided in this period is to enable the child to know and accept himself, to socialize, to adapt to the school, to enable the child to discover his interests and abilities, to develop problem-solving skills, to identify children with special educational needs, to determine the readiness of the child in the transition to primary education and to provide guidance services to families.

In the examinations carried out, it was found that after the activation of the guidance service, which was removed from the pre-school education institutions in 2014, the studies about the pre-school education guidance services were inadequate and especially the studies including the guidance counselors, pre-school teachers and parents were insufficient. Based on this need, current research is designed to evaluate the guidance services applied in pre-school education institutions in line with the opinions of the school guidance counselor, preschool teacher, and parent.

\section{Method}

This research is designed in a phenomenological pattern, which is one of the qualitative research methods in order to determine the perceptions, and experiences of the participant groups about guidance services. Participants of the research consisted of three groups since the guidance-related statements in the 2013 preschool education curriculum include guidance counselors, preschool teachers, and parents whose children attend these schools. Accordingly, fifteen from each group and 45 participants in total were included in the research. Participants were selected from Kırşehir and Kayseri and interviews were held in 2019. One of the ways to increase the validity in qualitative researches in which data is collected through interviews is to present the process of determining the research group in a systematic way. In this line, the study group was selected according to the basic requirement for the selection of the study group proposed by Robinson (2014). The data obtained were subjected to content analysis by independent coders and the findings of the research were created.

\section{Results}

The codes resulting from the analysis of the interviews were collected under five categories. These are the guidance activities, the benefits of guidance, the reasons for success, the problems, and the suggestions. In the guidance activities category, the participants stated that they provide guidance to parents, teachers, and children. The participants stated that the benefits of guidance are expert support, solution of problems, reduced workload for teachers, early intervention, and well-being. In another category, the reasons for the 
success of guidance were expressed as cooperation and child-centered guidance, while the problems encountered were expressed as parents' indifference, communication with children, cooperation, and physical conditions. Finally, the participants offered field training, improving physical conditions, increasing cooperation, and staffing as suggestions.

\section{Conclusion and Discussion}

During the interviews, the participant groups provided important opinions to shed light on the guidance services implemented in preschool education institutions. In the category of guidance activities, the participant groups stated that guidance services were provided to parents, teachers, and children and that they also provide guidance activities in the classroom. In our research, the findings that guidance services are mostly provided as seminars and one-to-one interviews with parents are similar to the findings in the studies conducted by Akgün (2010) and Kanak, Ersoy \& Yerliyurt (2018). Preschool teachers and guidance counselors stated that besides counseling services for parents, one-on-one interviews or counseling activities were held for children and teachers. However, the point to be considered in the guidance activities to be organized one-on-one or in the classroom with children is the use of plays, drama, drawings, finger plays and similar activities. Guidance activities organized in this way will be more efficient (Pardeck \& Pardeck, 1989; Van Hoose, Peters ve Leonard, 1970). It is possible to see how these suggestions of experts are effective in solving the problems experienced by children in the findings of our research. The current research suggested that child-centered guidance is an important factor in the success of preschool guidance services.

The cooperation is very important for preschool guidance services because it was emphasized by participants groups in the categories related to the reasons for success, the problems, and the suggestions. The finding in the study conducted by Aliyev, Erguner-Tekinalp, Ulker \& Shine-Edizer (2012) differs from the finding in our research that the guidance counselors cooperates with teachers and parents. This difference may have resulted from the fact that guidance services in preschool education institutions have been seen more important in recent years than in previous years or that parents and teachers have a better understanding of the importance of guidance services. The research findings showing that families and preschool teachers cooperate with guiding counselors and evaluation of preschool teachers' counseling activities as important (Eren, 2014; Kardeş \& Akman, 2014) support our assumption. Therefore, it is understood from the findings of our research that collaboration, which is important for classroom applications due to the nature of preschool education, has a key role important for guidance services, and why it is important for these three groups to cooperate.

It is thought that this research will make important contributions to the literature by examining the preschool guidance services within the context of preschool teachers, guidance counselors, and parents. In line with the results of the research, the following suggestions can be presented: Preschool guidance programs can be revised by analyzing the expectations and needs of all stakeholders such as preschool teachers, guidance counselors, parents, and school administrators. Regardless of the number of children, at least one 
guidance teacher staff can be allocated in each preschool education institution. Different courses for guidance practices in preschool education can be included in the guidance and psychological counseling undergraduate programs of universities. Informative parent education programs can be organized for the importance and functions of the guidance services offered in the pre-school period. 


\section{GİRIŞ}

Erken çocukluk yılları insan yaşamında gelişimsel açıdan önemli bir yere sahiptir. Bu yaşlarda bilişsel, dil, sosyal, duygusal ve fiziksel gelişimde önemli değişimler yaşanır (Kagan, Moore ve Bredekamp, 1995). Bu yaş aralığındaki çocukların gelişim ve öğrenmelerini desteklemeye yönelik çabalar gün geçtikçe artmaktadır. Örneğin, son yirmi yılda gelişmiş ve gelişmekte olan ülkeler okul öncesi çocuklarının eğitim kurumlarına devamını sağlamak için çeşitli girişimlerde bulunmuşlardır. Bu girişimler özellikle dezavantajlı çocukların okul öncesi eğitim kurumlarına devamını sağlamak için yapılmıştır (The Organization for Economıc Co-Operatıon and Development [OECD], 2017). Çünkü okul öncesi eğitim çocukların akademik becerilerin ediniminde ve bunları ileriki yıllarda kullanımında (Apps, Mendolia ve Walker, 2013; Cortazar, 2015; Mağden ve Şahin, 2002), sağlıkla ilgili istendik kazanımların elde edilmesinde (Lumeng, Kaciroti ve Frisvold, 2010) ve ekonomik fayda sağlanmasında (Heckman, 2006) oldukça etkilidir. Okul öncesi eğitimden istendik sonuçların elde edilmesinde eğitimin kaliteli olması uzmanların en önemli öncelikleri olmuştur. Okul öncesi eğitimde kaliteyi oluşturan temel unsurlar sınıf ortamı, sınıftaki çocuk sayısı, öğretmenin pedagojik yeterlilikleri ve öğretmen-çocuk iletişimidir (Sheridan, 2007). Bunun yanında kaliteyi oluşturan unsurlardan biri de okul öncesi eğitim programıdır. Eğitsel faaliyetlerin önemli bir unsuru olan program öğretmenlerin eğitsel önceliklerinin belirlenmesini sağlar ve okul öncesi eğitim için önemli olan paydaşların özellikle de çocukların ihtiyaçlarını yansıtır (Aral ve Can Yaşar, 2014; Erden, 1988; OECD, 2017; Stabback, 2016).

Program, sınıf içi ve sınıf dışında yürütülecek olan eğitim faaliyetlerinin genel çerçevesini belirlemede etkili olduğu için okul sisteminin temelini oluşturur (Erden, 1988). Türkiye'de okul öncesi eğitim kurumlarında uygulanmakta olan program, 2013 yllında uygulamaya geçmiş ve hâlen okullarda uygulanmaktadır. Bu program ortaya çıkan yeni ihtiyaçlar doğrultusunda yapılan güncellemelerle, çocuk merkezli ve gelişimsel açıdan uygun bir program özelliği taşımaktadır (Milli Eğitim Bakanlığ1 [MEB], 2013). Bu programın özellikler bölümünde dikkat çekici olan ve önceki programda yer almayan ifadelerden biri rehberlikle ilgilidir (MEB, 2006; MEB, 2013). Güncel programda bu özellikle ilgili olarak şu ifadelere yer verilmiştir;

\section{"Öğretmenlerin, rehber ögretmenlerle işbirliği içerisinde çalısması, çocuklarm gelişimlerinin desteklenmesinde ve ekip çalısmasınn sağhkkl bir şekilde yürütülmesinde önemlidir. Bu işbirliğinin ailelerin eğitimlerine de önemli katkı sağlaması beklenmektedir.” (MEB, 2013. s.17).}

Bu özellik, okul öncesi eğitim kurumlarında uygulanmakta olan rehberlik hizmetlerini dikkat çekici bir konu hâline getirmiştir. 


\section{Okul Öncesi Eğitimde Rehberlik Hizmetleri}

Okul öncesinde sunulan rehberlik hizmetleri üst öğrenim kurumlarında sunulan rehberlik hizmetlerine göre farklılaşmaktadır. Bu yaş grubunda yer alan çocuklar; henüz okuma yazma, kendi duygu ve düşüncelerini ifade edebilme gibi bir dizi becerilerin gelişimini tam olarak tamamlayamadıkları için direkt bir uzman tarafindan sunulan rehberlik hizmeti yerine, okul rehber öğretmeni öncülüğ̈nde sınıf öğretmeni ve ailesi üzerinden sunulan dolaylı bir rehberlik hizmeti alır.

Diğer yandan okul öncesi eğitimde rehberlik hizmetleri çocukların içinde bulundukları gelişim döneminin özelliklerinden dolayı önemli bir yere sahiptir. $\mathrm{Bu}$ dönemde verilecek rehberlik hizmetlerinin amacı, çocuğun kendini tanıması ve kabul etmesi, sosyalleşmesi, okula uyumunun sağlanması, çocuğun ilgi ve yeteneklerini keşfetmesinin sağlanması, problem çözme becerilerinin geliştirilmesi, özel eğitim ihtiyacı olan çocukların belirlenmesi, çocuğun temel eğitime geçişteki hazırbulunuşluğunun tespit edilip ailelere rehberlik hizmeti verilmesi olarak sıralanabilir (Tan, 1992; Kuzgun, 2013; Özgüven, 2001; Yeşilyaprak, 2019). Bununla birlikte rehberlik hizmetleri, çocuğun yaşam alanında yer alan aile, öğretmen, okul yönetimi, arkadaşları ve yakın çevresindeki tüm bireylerle iş birliği ve etkileşim içinde ve aynı zamanda koruyucu, önleyici ve krize müdahale hizmetlerini de içerecek şekilde sunulan kapsamlı bir hizmet bütünlügünden oluşmaktadır (Kanak, Ersoy ve Yerliyurt, 2018).

Avrupa'da 1960'lı yıllarda ortaya çıkmış olan gelişimsel rehberlik yaklaşımı ülkemizde 2006 yılı itibarıyla MEB'in okul rehberlik programlarına yansımıştır (Nazlı, 2016). Aynı zamanda bu yaklaşımın özünü oluşturan “ağaç yaşken eğilir” atasözünde de vurgulandığ1 gibi rehberlik hizmetlerinin erken çocukluk yıllarından itibaren verilmeye başlanmasının önemli olduğu anlayışı benimsenmiştir.

Gelişimsel rehberlik anlayışı çerçevesinde hazırlanmış ve okul öncesi kurumlarda hâli hazırda yürütülen rehberlik programı; okula ve çevreye uyum, eğitsel gelişim, kendini kabul, kişiler arası ilişkiler, aile ve toplum, güvenli ve sağlıklı hayat, mesleki gelişim olmak üzere yedi yeterlik alanından oluşmaktadır (MEB, 2012). Bu yeterlik alanlarının etkililiğini artırmak için, okul yöneticilerinden, okul rehber öğretmenine, ana sınıfı öğretmeninden, çocuğun velisine kadar uzanan birtakım görev ve beklentiler vardır. Bu beklentiler, MEB’in Talim Terbiye Kurulu Başkanlığınca 2012 yılında yayınladığ1 "Okul Öncesi Rehberlik Programı” kitapçığında şöyle sıralanmaktadır:

Okul Yönetiminden Beklentiler: Okul müdürü, pozisyonu gereği okuldaki diğer tüm etkinliklerde olduğu gibi rehberlik etkinliklerinin yürütülmesinde de lider konumundadır. Bu amaçla okul 
müdürlerinin rehber öğretmen-okul öncesi öğretmeni ve veliler arasındaki koordinasyonu sağlama, gerekli fiziki ortamın hazırlanması ve uygulamalar sırasında ortaya çıkabilecek olan sorunların giderilmesi gibi görevleri bulunmaktadır (MEB, 2012).

Okul Rehber Ögrretmeninden Beklentiler: Okul öncesi rehberlik hizmetlerinin önemli bir aktörü olan rehber öğretmeninden rehberlik programını hazırlaması, okul öncesi öğretmenlerinin programı uygulamalarında destek olması ve bu uygulamalarla ilgili öğretmenlere geri bildirimler vermesi beklenir. Ayrıca rehberlik etkinliklerinde gerekli olacak materyal ve ölçme araçlarını sağlaması, program içerisinde yer alan rehberlik etkinliklerini ilgili zamanlarda gerçekleştirmesi, programın genel değerlendirmesini yapması ve görülen aksaklıkları tespit etmesi ve gerekli önlemlerin alması da önemli görevlerindendir. Son olarak rehber öğretmenlerden okul yönetimi, okul öncesi öğretmenleri ve veliler arasında iş birliği yapması, velileri program konusunda bilgilendirerek aile eğitim programları uygulaması da beklenir (MEB, 2012).

Okul Öncesi Eğitimi Ögrretmeninden Beklentiler. Rehberlik faaliyetlerinin başar1lı bir şekilde uygulanabilmesi için okul öncesi öğretmenlerinin programı ve genel yapısını anlamaları gerekir. Bu doğrultuda okul öncesi eğitim öğretmenlerinin, konu başlıklarına yönelik araştırma yapması, rehber öğretmenle eş güdümlü çalışması ve böylece uygulamalara hazırlıklı olması beklenir. Ayrıca öğretmen, rehberliğe yönelik uygulamalarını çocuklara tutum, beceri ve değer kazandırmayı sağlayacak yaşantılar sunacak şekilde planlamalıdır. Bu uygulamalar sırasında öğretmen çocukların kendilerini ifade edebilmelerine olanak sağlamalıdır. Çocuklar için gerektiğinde pekiştireçler vermesi ve kazandırılmak istenen beceriler için model olması beklenir. Son olarak öğretmenden velilerle işbirliği yaparak çocukların gelişimlerini takip etmesi ve velilerin rehberlik çalışmalarına katılmasını sağlaması beklenir (MEB, 2012).

Aileden/Veliden Beklentiler: Programın başarısının arttırılması için iş birliği sürecinin içerisinde ailelerin de olması önemli bir gerekliliktir. Bu doğrultuda ailelerden çocuklarına model olmaları, okuldaki rehberlik uygulamaları için çocuğun gelişimi hakkında bilgi sağlamaları, değerlendirme konusunda okula destek sağlamaları ve okulda yürütülen rehberlik faaliyetlerine katılmaları beklenir (MEB, 2012).

Okul öncesi eğitimde öğretmen-çocuk-rehber öğretmen (psikolojik danışman) ve ebeveynler arasındaki olumlu ve işbirliğine dayalı bir ilişkinin kurulmuş olması rehberlik hizmetlerinin amacına ulaşmasında büyük önem taşımaktadır (Gençtanırım-Kurt, 2020). 


\section{Araştırmanın Amacı}

Okul öncesi eğitim, çocuğun gelişiminde oldukça önemli bir eğitim basamağıdır. Çocukların bu dönemdeki gelişimlerini desteklemede büyük katkılar sağladığı bilinen rehberlik hizmetlerinin bu kurumlarda planlı ve programlı bir şekilde sunulması önem arz etmektedir. Ülkemizde 2011 yllinda resmî makamlarca yapılan değişikliklerle okul öncesi eğitim kurumlarında rehberlik servisinin aktif hâle getirilmesi kararlaştırılmıştır. Ancak 2014 yılında okul öncesi rehberlik hizmetleri kesintiye uğramıştır (Eren, 2014). Bu yıllar arasında aktif olan okul öncesi rehberlik hizmetlerine yönelik çeşitli araştırmalar tasarlanmıştır. Bu araştırmalar nicel, nitel ve karma yöntemlerde düzenlendiği gibi farklı örneklem grupları dâhil edilerek farklı veya birbirini destekleyen sonuçlar elde edilmiştir (Akalın, 2014; Bilgin, 2017; Eren, 2014; Kardeş ve Akman, 2016; Kılıçoğlu, 2013; Nas, Sak ve Sak, 2017; Tekin, 2012; Yerlikaya, Sak ve Şahin-Sak, 2014). Ancak yapılan incelemelerde, 2014 yllinda okul öncesi eğitim kurumlarında kaldırılan rehber öğretmen norm kadrosunun tekrar aktif hâle getirilmesinin ardından okul öncesi eğitim rehberlik hizmetlerine yönelik araştırmaların ve özellikle de rehber öğretmen, okul öncesi öğretmeni ve ebeveynlerin dâhil edildiği araştırmaların yetersiz olduğu tespit edilmiştir. Bu ihtiyaçtan yola çıkarak; mevcut araştırma okul öncesi eğitim kurumlarında uygulanan rehberlik hizmetlerinin okul rehber öğretmeni, öğretmen ve ebeveyn görüşleri doğrultusunda değerlendirilmesi amacıyla düzenlenmiştir. Çalışmanın okul öncesi eğitim kurumlarında uygulanan rehberlik hizmetleri uygulamalarına olumlu yönde katkı sağlayacağ1 düşünülmektedir.

\section{YÖNTEM}

Bu araştırma, okul öncesi eğitim kurumlarında yürütülmekte olan rehberlik hizmetleri ile ilgili okul öncesi eğitim rehberlik paydaşlarının görüsslerini almak ve dolayısıyla bu kurumlarda yürütülen rehberlik hizmetlerinin değerlendirilmesi amacıyla düzenlenmiştir. Bu araştırma, katılımcı grupların rehberlik hizmetleri ile ilgili algılarını, yaşantı ve deneyimlerini belirlemek amacıyla nitel araştırma yöntemlerinden fenomonolojik desende tasarlanmıştır. Fenomonoloji araştırmalarında farkında olunan ancak derinlemesine ve ayrıntılı bir anlayışa sahip olunmayan olgulara odaklanılarak bireyin, bu olguya ilişkin yaşantılarını, algılarını, deneyimlerini ve olguya yüklediği anlamları ortaya çıkarmak amaçlanır (Yıldırım ve Şimşek, 2016).

\section{Katılımcilar}

Bu araştırmada, 2013 okul öncesi eğitim programındaki rehberlik ile ilgili ifadelerde okul öncesi eğitim kurumlarında görev yapmakta olan rehber öğretmenler, okul öncesi eğitim öğretmenleri ve çocukları bu okullarda eğitim alan ebeveynlerden bahsedildiği için katıllmcılar üç gruptan 
oluşmaktadır. Rehberlik servisinin hizmet verdiği okullar araştırmanın temel veri kaynakları olarak düşünülen grupların yer aldığı kurumlardır. Görüşmelerle verilerin toplandığı nitel araştırmalarda, geçerliliği artırmanın yollarından biri de katılımcıların tespit edilmesi sürecinin sistematik bir şekilde sunulmasıdır. Bu doğrultuda katılımcılar Robinson (2014) tarafından önerilen katılımcı seçimi ile ilgili temel gerekliliklere göre seçilmiştir. İlk gereklilik, araştırma konusu ile ilgili evrenin tespit edilmesidir. Bu aşamada araştırmanın evrenini, rehberlik hizmetlerinin yürütüldüğü anaokulları oluşturmaktadır. Bu evrenden araştırmaya dâhil edilecek grubun tespit edilmesinde okul öncesi programında rehberlik hizmetleriyle ilgili ifadeler referans alınmış ve yukarıda da bahsedildiği gibi üç grup (rehber öğretmen, okul öncesi öğretmeni ve ebeveyn) araştırma grubunu oluşturmuştur. Böylece hem katılımcı çeşitliliği sağlanmış hem de fenomonolojik yaklaşımın özünde yer alan "herhangi bir olguyla ilgili kişisel görüş ve deneyimlere” farklı bakış açılarıyla katkı sağlanacağı düşünülmüştür. İkinci gereklilik, katılımcı sayısına karar vermektir. Nitel araştırmalarda sorgulanan olguyla ilgili derinlemesine bilgi elde edilmesi amaçlanır. Bu sebeple katılımcı sayısı nicel araştırmalardaki gibi yüksek sayıda olması yerine daha az sayıda belirlenir (Ritchie, Lewis, Elam, Tennant ve Rahim, 2014). Bu doğrultuda, araştırmaya her bir gruptan on beş kişi ve toplamda 45 katılımcı dâhil edilmiştir. Üçüncü gereklilik ise katılımcıları belirlemede esas alınan örneklem yöntemleridir. Mevcut araştırmada öncelikle Kırşehir ilinde rehberlik hizmetlerinin yürütüldüğü okullar az sayıda olduğu için bütün okullar araştırmaya dâhil edilmiştir. Ancak yeterli sayıda okul olmadığ için $(\mathrm{N}=6)$ Kayseri ilinden de dokuz okul araştırmaya dâhil edilmiştir. Kayseri ilindeki okulların belirlenmesinde kartopu örneklem yöntemi kullanılmıştır. Bu yönteme göre görüşmelerin yapıldığı kişi veya kişilerin önerileri ile sonraki görüşmeciye karar verilir. Bu şekilde katılımcılar daha gönüllü katılırlar (Robinson, 2014). Bu araştırmada okulların müdürleri veya rehber öğretmenlerinin önerileri doğrultusunda sonraki okula karar verilmiştir. Ayrıca bu okullarda görüşülecek olan öğretmenlerin ve ailelerin seçilmesinde “amaçlı örnekleme” yöntemi esas alınmış ve rehberlik servisini aktif şekilde kullananlar dâhil edilmiştir. Bu aşamada da rehber öğretmenlerin önerileri doğrultusunda on beş okul öncesi öğretmeni ve on beş ebeveyn belirlenmiştir. Katılımcıların demografik özellikleri incelendiğinde rehber öğretmenlerin tamamının rehberlik ve psikolojik danışmanlık lisans programından mezun oldukları, 12 rehber öğretmenin okul öncesi eğitim kurumunda ilk yılını, üçünün ise 2. yllını çalıştıkları tespit edilmiştir. Ayrıca rehber öğretmenlerin 3’ü erkek, 12'si ise kadındır. Okul öncesi öğretmenlerinin tamamı okul öncesi eğitim öğretmenliği programından mezun oldukları ve tamamının kadın olduğu tespit edilmiştir. Öğretmenlerin 3’ü meslekte 20 yıldan fazla çalıştıklarını, 9'u 6-10 yıl arasında ve 3’ü ise ilk beş yılını çalıştıklarını belirtmiştir. Ayrıca öğretmenlerin 7'si 5-6 yaş grubundaki çocuklarla, 8’i 4-5 yaş grubundaki çocuklarla çalıştıklarını ifade etmiştir. Ayrıca araştırmaya katılan ebeveynlerin tamamı çocukların 
annesidir. Annelerin 4'ü lisans, 5’i lise, 3’ü ortaokul, 2'si ilkokul ve biri de doktora mezunu olduğunu belirtmiştir.

\section{Veri Toplama Süreci ve Analiz}

Araştırmanın veri toplama aşamasında, öncelikle İl Milli Eğitim Müdürlüklerinden resmi izinler alınmış ve okul müdürleri ve okuldaki rehber öğretmenlerle irtibata geçilerek araştırmanın amacı hakkında bilgi verilmiştir. Kırşehir ilinde rehberlik hizmetlerinin yürütüldüğü okullardaki rehber öğretmenler araştırmaya katılmaya gönüllü olmuştur ve böylece rehberlik hizmetinin yürütüldüğü bütün okullar araştırmaya dâhil edilmiştir. Kayseri ilinde ise yukarıda belirtilen örneklem sürecine göre okullar ve katılımcılar tespit edilmiştir. Gerekli verileri elde edebilmek amacıyla yarıyapılandırılmış görüşme formu düzenlenmiştir. $\mathrm{Bu}$ form rehber öğretmenler, okul öncesi öğretmenleri ve ebeveynler için ayrı ayrı düzenlenmiştir. Rehber öğretmenler ve okul öncesi öğretmenleri için düzenlenen formda 7 soruya, ebeveynler için düzenlenen görüşme formunda ise 6 soruya yer verilmiştir. Taslak görüşme sorulanı, okul öncesi eğitim alanından iki, rehberlik ve psikolojik danışmanlık alanından bir uzmana inceletilmiştir. Uzman görüşleri doğrultusunda taslak sorular üzerinde gerekli düzenlemeler yapılmış ve bazı sorular birleştirilmiştir. Üç okul öncesi öğretmeni ve üç ebeveynden oluşan altı kişilik grupla ayrı ayrı pilot görüşmeler yapılmıştır. Pilot görüşmeler sonucunda yapılan birkaç değişiklikle, görüşme sorularının veri toplamak için uygun olduğuna karar verilmiştir. Son hâliyle görüşme formu iki bölümden oluşmuştur. Birinci bölümde, demografik bilgilerle ilgili sorular, ikinci bölümde ise okul öncesi rehberlik hizmetlerinin değerlendirilmesiyle ilgili sorular yer almıştır. Araştırma sürecinin tamamında gerekli bilimsel ve etik ilkelere uyulmuştur. Katılımcılara araştırma ile ilgili gerekli bilgilendirmeler yapılmış, gönüllü onam formlarını doldurarak çalışmaya katılımları sağlanmıştır. Görüşmeler 2019 yılı ocak ve nisan ayları arasında öğretmenlerin çalıştı̆̆ı okullarda sessiz bir ortamda gerçekleştirilmiştir. Görüşme sırasında, ses kayıt cihazları kullanılmış ve görüşmeler 15-30 dakika arası uzunlukta sürmüştür. Elde edilen verilerin analizinde, içerik analizi yöntemi kullanılmıştır. İçerik analizi dört aşamada gerçekleştirilmiştir (Patton, 2002; Yıldırım ve Şimşek, 2016). İlk aşamada, ses kaydı cihazındaki veriler yazılı hâle getirilmiştir ve yazılı dokümanla sesli verinin uyuşup uyuşmadığı kontrol edilmiştir. Ardından görüşmelerin yazılı dokümanları bir kez okunmuştur ve bu okuma sırasında ifadelerin yanlarına kısa notlar alınmıştır. Bu notların, görüşmelerin akışı hakkında fikir vereceği ve kodlamada kolaylık sağlayacağı varsayılmıştır. İkinci aşamada, kodlamalar yapılmıştır. Kodlama, yazılı görüşme dokümanları üzerine kaydedilen notlardan da faydalanılarak, katılımcıların görüşlerini en iyi ifade edecek şekilde oluşturulmuştur. Son aşamada ise oluşturulan kodlar bir araya getirilmiş ve ortak anlamlarına göre kategoriler altında gruplandırılmıştır. Bu aşamalar iki bağımsız kodlayıcı tarafından 
yapılmıştır. Bu sürecin güvenirliğinin tespiti için Miles ve Huberman'ın (1994) kod uyuşum yüzdesi formülü kullanılmış ve uyuşum oranının \% 91 olduğu tespit edilmiştir. Bu sonuç kabul edilebilir aralıkta olduğu için bağımsız kodlayıcılar arasındaki uyuşumun kabul edilebilir olduğu söylenebilir. Görüş farklılıkların olduğu kodlarla ilgili kodlayıcılar tekrar bir araya gelmişler ve bu kodlar hakkında fikir birliğine varmışlardır. Ayrıca rehber öğretmen, okul öncesi öğretmeni ve ebeveynlerin görüşlerinin yer aldığı alıntılara ilgili bölümlerde yer verilmiştir. Alıntılarda etik kurallar gereği katılımcıların kim olduğunu belirtecek ifadeler yerine rehber öğretmenler RÖ 1, 2, 3.., okul öncesi öğretmenleri OÖÖ 1, 2, 3... ve ebeveynler E 1, 2, 3 ... olarak kısaltılmıştır.

\section{BULGULAR}

Bu bölümde yapılan görüşmelerin analizi sonucunda ortaya çıan sonuçlar sunulmuştur. Katılımcı ifadelerinden ortaya çıkan kodlar beş kategori altında toplanmıştır. Bunlar; rehberlik faaliyetleri, rehberliğin faydaları, başarı nedenleri, problemler ve öneriler şeklindedir. Kategoriler ve bu kategorilere ait kodlar tablolar halinde sunulmuştur.

\section{Kategori I: Rehberlik Faaliyetleri}

Tablo 1. Kategori kodlar1 ve frekanslar1

\begin{tabular}{lccc}
\hline Kodlar & RÖ & OÖÖ & E \\
\hline Ebeveyne rehberlik & 17 & 8 & 11 \\
Çocuğa rehberlik & 10 & 3 & 4 \\
Sınıff iç rehberlik & 10 & 7 & 2 \\
Öğretmene rehberlik & 5 & 5 & - \\
\hline
\end{tabular}

RÖ: Rehber Öğretmen, OÖÖ: Okul Öncesi Öğretmeni, E: Ebeveyn

Görüşme verilerine yapılan analizlerde ortaya çıkan kategorilerden birisi "rehberlik faaliyetleri" olmuştur. Görüşülen grupların bu kategori altında en çok bahsettikleri rehberlik faaliyeti, ebeveyne rehberlik olmuştur. Rehber öğretmenler, ebeveynler ve okul öncesi öğretmenleri ebeveynlere yapılan rehberlik faaliyeti olarak ebeveynlere seminerler düzenlendiğinden ve ebeveynlerle bireysel rehberlik görüşmeleri yapıldığından bahsetmişlerdir. Bu rehberlik hizmetiyle ilgili katılımcılar görüşlerini şu şekilde ifade etmişlerdir;

“...rehber ögretmenimiz seminerler yapıyor, bunun dışında da birebir görüsmelerimiz, oluyor”...

(E12).

“...ebeveynlere yönelik seminerler ve birebir görüsmeler yapılyyor...” ( OÖÖ8).

"...uygun arahklarla ebeveyn görïsmeleri yapıyorum ve bu görüşmelerde ailelere cocuklarn gelisimi hakekinda bilgiler veriyorum. Verdiğim bu bilgiler sonucunda velilerden olumlu dönütler alyyorum..." (RÖ4). 
“...iki haftada bir aile seminerlerimiz oluyor. Seminerler rehberlik konular veya mahremiyet eğitimi, teknoloji bă̆ımlilĭğ, öfke yönetimi gibi konular hakekında yapıliyor...” (RÖ12).

Rehber öğretmenler, okul öncesi öğretmenleri ve ebeveynler çocuklara yönelik rehberlik faaliyetleri yapıldığını ifade etmişler ve bu faaliyetlerin çocuklarla birebir görüşme ve çocukların gözlemlenmesi şeklinde gerçekleştiğini vurgulamışlardır. Katılımcı grupların görüşlerine örnek olarak;

“...okula uyum aşamasında çocuklarn kaygularmın çözümü için çocuklarla bireysel görüsmeler yaptım...” (RÖ6).

“...problemi olan çocuklar sinf ortaminda göəllemliyorum...” (RÖ9).

“... rebber ögretmen sinf içerisinde çocuklarn gö̊lemliyor...” (OÖÖ12).

“...baz̧en çocukla bire bir görüsüyor ve biðden önce çocukla görüsmesi daha etkili oluyor...” (E11).

Katılımcı gruplar tarafindan vurgulanan bir diğer rehberlik faaliyeti ise sınıf içerisinde yapılan rehberlik olmuştur. Bu faaliyetlerde genellikle davranış problemleri, okula uyum konuları ele alındığ1 ve rehber öğretmenlerinin bunları çocukların gelişimsel özelliklerine uygun bir şekilde yapmaya çalıştıkları anlaşılmaktadır. Örneğin;

“...ayda bir her simfta mutlaka rehberlik etkinliği düzenliyoruz: Mesela öfke kontrolï, zorbahk ve cinsel istismar konusunda ayda bir her sinffta grup çalısması yapıyoruæ...” (RÖ7).

“... rehber ögretmen simfta mahremiyet eğitimini anlattı, materyallerle kulland ve çeşitli etkinlikler yaptı...” (ОÖÖ6).

“... rebber ögretmenimiz, socuğumun simıfina geliyor ve önemli olan konularda onlara bilgiler veriyor.

Mesela geçenlerde çocuklara akran zorbah̆̆ ile ilgili bilgi vermiş...” (E13).

Öğretmene yapılan rehberlik, hem rehber öğretmenler hem de okul öncesi öğretmenlerinin ifade ettiği rehberlik faaliyetlerinden birisidir. Bu faaliyetlerin genelde öğretmenle görüşme şeklinde olduğu, aynca bu görüşmelerin çocukların problemleri ve öğretmenlerin yaşadığı zorluklarla ilgili olduğu anlaşılmaktadır. Rehber ve okul öncesi öğretmenleri görüşlerini şu şekilde ifade etmişlerdir;

“...çocuklarda gö̋lemlediğim sıkıntıl durumlarla ilgili ne yapamayacağım bilemediğimde rehber ögretmenden yardim aliyorum..." (OÖÖ5).

"...ögretmen çocukta yaşanan problemlerde ya da simfta yetmediği durumlarda bana başvuruyor. Ben de ögretmenlere destek oluyorum...” (RÖ3). 


\section{Kategori II: Rehberliğin Faydaları}

Tablo 2. Kategori kodları ve frekansları

\begin{tabular}{|c|c|c|c|}
\hline Kodlar & RÖ & OÖÖ & $\mathbf{E}$ \\
\hline Uzman desteği & 24 & 22 & 19 \\
\hline Problem çözümü & 8 & 10 & 7 \\
\hline Azalan iş yükü & 12 & 10 & 2 \\
\hline Erken müdahale & 15 & 2 & 5 \\
\hline İyi hissetme & 2 & 3 & - \\
\hline
\end{tabular}

RÖ: Rehber Öğretmen, OÖÖ: Okul Öncesi Öğretmeni, E: Ebeveyn

Yapılan analizlerde ortaya çıkan kategorilerden birisi rehberlik çalışmalarının faydalarıdır. $\mathrm{Bu}$ kategori altında rehber öğretmenler, ebeveynler ve okul öncesi öğretmenler tarafindan en çok ifade edilen rehberliğin faydası uzman desteği olmuştur. Rehberlik hizmetlerinin, öğretmenlerin yanı sıra özellikle ebeveynler için önemli bir destek olduğu gruplar tarafindan ifade edilmiş ve uzman desteği genelde okula uyum, davranış problemleri, kaynaştırma, arkadaş ilişkileri, akran zorbalı̆ğ, dikkat eksikliği, teknoloji bağımlılı̆̆1 ve korkular konusunda olmuştur. Uzman desteğine ilişkin örnek görüşler şu şekildedir;

“...karar veremediğimiz, problemler yaşadiğımı durumlarda bize yardımc olacak, yol gösterecek. alanında u₹man kişilere ibtiyacımı oluyor ve rebber ögretmen bize destek vererek bu ibtiyacımıฉ? karşıllyor...” (E9).

“... aileler çocuklarmm okula uyumlar konusunda kaygz yaşzyorlar. Ama rehber ögretmenle konustuklar zaman ikna oluyorlar ve o tedirginliklerini asıyorlar...” (OÖÖ7).

“...ben rehber ögretmenle ilk defa çalışzyorum. Bize katkıss çok oldu. Özellikle sinuf içi davranıs problemleri, teknoloji bağgmhlĭğ konusunda biz̨e desteği çok oldu...” (OÖÖ8).

“...ebeveynler çocuklarndaki davranıs problemlerini çözemediklerinde, bizden destek istiyorlar...” (RÖ8).

Rehberlik hizmetlerinin faydalarından bir diğeri de okul öncesi öğretmenlerinin ve ebeveynlerin karşılaştıkları problemlerin çözüme kavuşması olduğu katılımc1 grupların ifadelerinden anlaşılmaktadır. Çözülen problemler, genellikle (yukarıda) uzman desteği altında sıralanan problemlerdir. Gruplar için örnek görüşler şu şekildedir;

“...çocuğum okula gelmek istemiyordu. Kendim sebebini öğrenmeye çalıștım ama başarlı olamadım.

Rehber ögretmeninden destek aldım ve sorun çözü̈ldü...” (E10).

"...baz̨ çocuklar teknoloji bağımlısı olmus ve ebeveynler işin içinden çıkamıyor. Ebeveyn ve çocuk. geliyor, görüsüyoruz ve problemi çözüyoruz...” (RÖ12). 
“...̈̈z̧ellikle kaynaştırma ögrencilerinin ailelerinin yaşadĭg problemleri rebber ögretmenimiz̨in çözdï̈̆̈̈ne şabit oldum...” (OÖÖ15).

Rehberlik hizmetlerinin okul öncesi öğretmenlerine uzman desteği sağladığ1 gibi onların iş yükünü de azalttı̆̆1 rehber öğretmenler ve okul öncesi öğretmenlerinin ifadelerinden anlaşllmaktadır. Örneğin;

"...benim simfimda otizmli bir çocuk var. Bu ögrencimi baz̧en simifin kalabalĭğndan uzaklaştırmam ve sakinlestirmem gerekiyor. Ama ben yetişemiyorum, sinftan çıkamyorum. Bu durumda rehber ögretmenden yardim istiyorum, bana destek veriyor. Böylece hem ben hem de çocuk rahatlyyor..."(OÖÖ1).

“...davranıs problemleri, beslenme, problemleri yaşayan çocuklarn aileleri gelip bize kapıdan soru soracaklarna, rehber ögretmene gidiyorlar ve buda ebeveynlerin bize yoğunlaşmasin engellemis oluyor..." (OÖÖ10).

"... çocuk okula ilk geldiği zaman ögretmen tek başına ilgilenemiyor. Bu süre zarfinda çocuğun adapte olması için çocuğu gözlemliyorum, ebeveyn ile görüsü̈orum, ögretmenle görüsü̈yorum, çocuk ile görüsüyorum. Böylece ögretmenin de işi kolaylassmış oluyor...” (RÖ1).

Görüşmelerde rehberlik hizmetlerinin bir diğer faydası ise erken müdahale olarak ifade edilmiştir. Her üç gruptan katılımcılar bu yaşlarda yapılan rehberlik müdahalesinin sonraki yaşlar için faydalı olacağını vurgulamışlardır. Örnek katılımcı görüşleri şu şekildedir;

“...̈̈zellikle biz̧im yas grubundaki cocuklara yapulan rebberlik problemlerin erkenden fark edilmesi ve müdahale edilmesi açısından oldukȩa faydahdir...” (OÖÖ1).

"...okul öncesi eğitim rehberliğin başlangzcıdır bence. Cünkü eğer bu yașta davranıs problemlerini tespit edebilirsem ileriki yaşlarda görülmesini engellemis olurum...” (RÖ2).

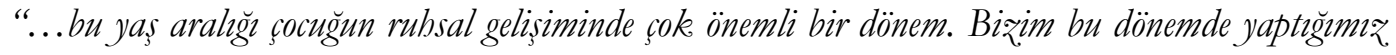
rebberlike etkinlikleri çocuklarn ileriki yaşamm olumlu yönde etkileyeceğgi için oldukeça faydalıdır...” (RÖ3).

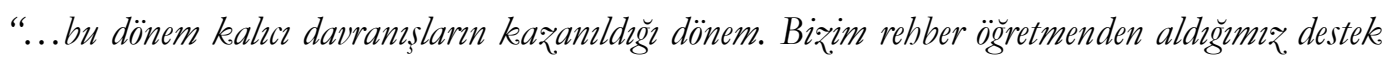
bu davranışların oluşturulması için oldukeşa faydah oluyor...” (E10).

Bu kategori altında "iyi hissetme" olarak kodlanan görüş hem rehber öğretmenler hem de okul öncesi öğretmenleri tarafından ifade edilmiştir. Okul öncesi öğretmenleri bu görüşü çocuklar için ifade ederken, rehber ögrretmenler ise hem çocuklar hem de kendileri için bu görüşü ifade etmişlerdir. Katılımcılar görüşlerini şu şekilde açılamışlardır; 


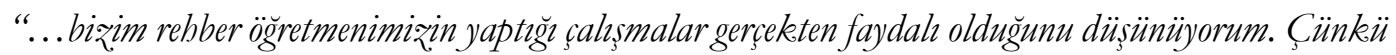
çocuk rebber ögretmeninin yanından geldiği zaman smifta çok mutlu oluyor...” (OÖÖ3).

"...rehberlik hocamiz simefta biže çalısma yaptı. Bu çalssma sirasinda çocuklarm daba çok etkilendiğini daha çok zevve aldiğgn, öğrenmeye daha çok hevesli olduklarm gördüm...” (OÖÖ7).

“...ögretmenler beni gerçekten dikkeate alyyorlar ve bölle etkinliklerin işe yaradığın da görïyorum. Bu beni doyuma ulastoryor ve mutlu oluyorum..." (RÖ11).

"...çocuk ilk başta okula uyum sağlayamaz iken benim yaptığım çalıs̆malar ile beni görüp okula sevinçle giriyor ve beni kucakliyor...” (RÖ1).

\section{Kategori III: Başarı Nedenleri}

Tablo 3. Kategori kodlar1 ve frekanslar1

\begin{tabular}{lccc}
\hline Kodlar & RÖ & OÖÖ & E \\
\hline Öğretmenle işbirliği & 17 & 8 & 2 \\
Ebeveynle işbirliği & 9 & 3 & 3 \\
Çocuk merkezli rehberlik & 5 & 3 & 2 \\
\hline RÖ:Rent
\end{tabular}

RÖ: Rehber Öğretmen, OÖÖ: Okul Öncesi Öğretmeni, E: Ebeveyn

"Başarı nedenleri” analizlerde ortaya çıkan kategorilerden bir diğeridir. Bu bölümde ebeveynler, öğretmenler ve rehber öğretmenler başarılı şekilde yürütülen rehberlik hizmetleri için iş birliğinin önemli olduğunu ifade etmişlerdir. Rehber öğretmenlerin bu işbirliğini hem okul öncesi öğretmenleri hem de ebeveynlerle kurduğu, görüşme verilerinden anlaşılmaktadır. Örnek olarak;

“... rehber ögrretmen farkh açıdan değerlendiriyor, biz farkh açıdan değerlendiriyoru\%: Öğretmen ve rehber ögretmenin iş birliğiyle sorun çok daha kolay halledilebiliyor...” (OÖÖ6).

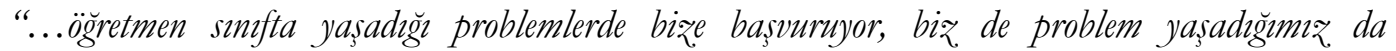

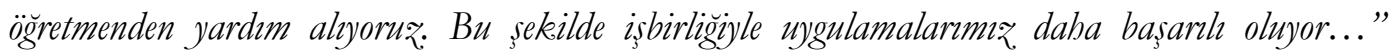
(RÖ3).

“... rebber öğretmenimizle görüstük. Biz kendi anne baba tutumu olarak. farkl düsüncelere sabiptik. Ama rehberlik servisi bize farkh bakıs açlar gösterdi. Ișbirliğigle problemimiž çözüm noktalar bulmaya çalıștı...” (E6).

“...baz̧en hareketli çocuklar ile ilgili durumlar ögretmenleri biz̧e aktaryor. Ben aileyle de işbirliüi kurarak bu problemlere çözü̈m bulmaya çalısıyorum...” (R12).

Bu kategori altında her üç grup tarafindan başarılı rehberliğin nedeni olarak ifade edilen diğer görüş “çocuk merkezli rehberlik "olmuştur. Katılımcılar bu görüşlerini ifade ederken rehberlik 
uygulamalarını oyunlaştırmayı, eğlenceli hale getirmeyi ve çocukların kendilerini ifade edebileceği yöntemleri kullanmayı vurgulamışlardır. Katılımcılar görüşlerini şu şekilde ifade etmişlerdir;

“...lisedeki bir çocuğa gidip bir konuyu direk anlatabilirsin fakat anaokulundaki çocuğa bunu yapamaðsın. Çünkü çocuklarm dikkeat süreleri uzun olmadĭğ için biə̧i çok fazla dinlemiyorlar. Bunun yerine yapacağımı seyleri oyunlaștırmak daha etkili oluyor...” (RÖ13).

“...cocuklarla çok fazla birebir psikolojik danısma yapulamiyor, çok fazla kendilerini açmyorlar.

Ben çocuklara resim çįdirerek kendilerini ifade etmelerini sağhyorum...” (RÖ12).

"...yine diyorum çocuklar oyunla daba güzel anliyorlar. Rebberlik. bölümlerinde ögretilecek. konu veya önemli gördükleri noktalarda oyunlarla, değģsik materyallerle çocuklara ögrretmek çok daba etkili oluyor...” (ОÖÖ6).

“... rehber ögretmenimizin rehberlik konularm çocuklara oyun veya drama gibi șeylerle aktarması problemlerin çözümü için önemlidir...” (E13).

\section{Kategori IV: Problemler}

Tablo 4. Kategori kodlar1 ve frekanslar1

\begin{tabular}{lccc}
\hline Kodlar & RÖ & OÖÖ & E \\
\hline Ebeveyn ilgisizliği & 12 & 4 & - \\
Çocuklarla iletişim & 5 & 2 & - \\
Isşbirliği & 3 & - & - \\
Fiziksel koşullar & 3 & - & - \\
Diğer & 2 & 2 & - \\
\hline
\end{tabular}

RÖ: Rehber Öğretmen, OÖÖ: Okul Öncesi Öğretmeni, E: Ebeveyn

Analizlerde ortaya çıkan kategorilerden birisi de rehberlik hizmetlerinde karşılaşılan problemlerle ilgili olmuştur. Bu kategori altında rehber öğretmenler ve okul öncesi öğretmenleri problemlerle karşılaştıklarını ifade ederken, ebeveynlerin herhangi bir problemle karşılaşmadıkları tespit edilmiştir. Rehber öğretmenler ve okul öncesi öğretmenlerin en çok ifade ettikleri problem “ebeveyn ilgisizliği” olmuştur. Özellikle ebeveynlerin düzenlenen faaliyetlere katılmamaları önemli bir problem olarak ifade edilmiştir. Örnek öğretmen ifadeleri şu şekildedir;

“...ebeveynler çalssmalar destekler gibi görünüyorlar ama bunun yeterli olmadiğgm düss̈nüyorum.

Üzerlerine düsen görevleri yapmaya özen göstermiyorlar...” (RÖ8).

“... ailelere yönelik sunum, seminer gibi çalışmalar yapuldiğznda gereken ilgiyi göstermediklerini düşünüyorum..." (RÖ10).

“...rebberlik seminerlerine ebeveynlerin katılım çok az oluyor...” (OÖÖ11).

Benzer şekilde, çocuklarla iletişim hem rehber öğretmenler hem de okul öncesi öğretmenleri tarafından ifade edilen problemlerden birisidir. Her iki gruptaki öğretmenler okul öncesi yaş 
çocuklarıyla rehber öğretmenlerin görüşme yapmakta zorlandıklarını ifade etmişlerdir. Örnek öğretmen görüşleri şu şekildedir;

“...benim karşılaştığım problemlerden en önemlisi bireysel görüsmelerde çocuklarn yas seviyelerine inmek oldu. Çünkü normal bir yetiskine söylediğin gibi küüük bir çocuğa söylediğinde anlama₹ ve yapmak istemez..." (RÖ8).

“... rehber ögretmenimiz okul öncesi dönemi çok iyi bilmiyor yani buraya gelmeden önce ögretmenimiz. liseden geliyorlar sanki çocuklar bu düzeyde gibi düsünüp davranyorlar bu yönde biraz, cocukla iletişim sılentısı yasıyoruq...” (OÖÖ4).

"İşbirliğinin olmaması" ve "fiziksel koşulların yetersiz oluşu” rehber öğretmenler tarafından ifade edilen problemden bir diğeridir. Örnek rehber öğretmen görüşleri şu şekildedir;

“... herhangi bir problem olduğunda ögretmen beni önemsemiyor, işbirlï̆ine yanaşmyor ve bu durum problem çözümü için sorun oluyor...” (RÖ1).

“...anaokullarnda önceden rehberlik servisi olmadiğndan dolay rebberlik odalar sıkıntılıdır. Mesela benim odam başka derme çatma, havasız, kǚn̈̈k ve düzensiz ve bu oda bana kötü hissettiriyor ...” (RÖ11).

Ayrıca diğer problemlerle ilgili olarak öğretmenler görüşlerini şu şekilde ifade etmişlerdir;

“...rehberlik hizmetlerinin denetlenmemesi önemli problemlerden birisidir. Denetlenmediği zaman yapılan çalışmalar kişinin vicdanına kahyor...” (RÖ13).

“... rehber ögrretmenin mesaisi 09-15.00 arası. Biæi ikili eğitim yapan bir okuluæ. Rehber ögretmen gittikten sonra bir problemle karşılaștı̆̆ımı̨da rebber ögretmen burada olmuyor...” (OÖÖ10).

“...rebber ögretmeninin uğraşması gereken önemli konular varken, onunla ilgili olmayan ve alan olmayan işlerle uğraşzyor...” (OÖÖ9).

\section{Kategori V: Öneriler}

Tablo 5. Kategori kodları ve frekansları

\begin{tabular}{lccc}
\hline Kodlar & RÖ & OÖÖ & E \\
\hline Alan eğitimi & 9 & 8 & 1 \\
İşbirliği & 6 & 2 & 2 \\
Kadro & 4 & 2 & 1 \\
Fiziksel koşullar & 5 & - & - \\
\hline
\end{tabular}

RÖ: Rehber Öğretmen, OÖÖ: Okul Öncesi Öğretmeni, E: Ebeveyn

Rehberlik hizmetlerinin daha etkili bir şekilde yapılmasına yönelik öneriler, bu araştırmada ortaya çıkan kategorilerden birisidir. Bu bölümde rehber öğretmenler, okul öncesi öğretmenleri ve 
ebeveynler tarafindan sıklıkla ifade edilen görüş, rehber öğretmenlerin alanda uzmanlaşmaları olmuştur. Bu uzmanlaşma üniversite yıllarında okul öncesinde rehberlik alan dersleri alarak olabileceği gibi öğretmenlik sürecinde mesleki bilginin arttırllmasına yönelik profesyonel gelişim çalışmalarıyla olabileceği özellikle rehber öğretmenler ve okul öncesi öğretmenleri tarafindan vurgulanmıştır. Örneğin;

"...çocuklara faydah olabilmek için bir rehber öğretmenin anaokuluna atanmadan önce ön eğitimden gecmesi gerekir...” (RÖ2).

“... rebberlik hizmetlerinin daha iyi yapulabilmesi için, rebber ögretmenlerin mesleki eğitim almalar gerekir...” (RÖ5).

“... rehber ögretmenler okul öncesinde sinf ortamina ve çocuklara daba bâkim olmalar için alanda u₹manlaşabilirler. Aynca üniversitede de alanlara yönelik eğitim almalılar. Örneğin okul öncesi,

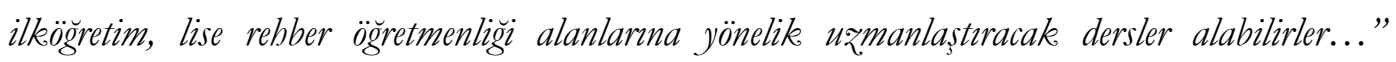
(OÖÖ10).

“...ögretmen okul öncesi çocuğuna yönelik, çok fą̧la bilgisinin olmadiğm düsünüyorum. Çocuğa nasıl yaklaşacă̆ konusunda bilgi sabibi olmalı, kendini gelistirmeli...” (E4).

Her üç grup tarafindan öneri olarak sıklıkla vurgulanan görüşlerden birisi de işbirliği olmuştur. Bu iş birliği yönetici-öğretmen-rehber öğretmen arasında kurulabileceği gibi rehber öğretmen ile ebeveyn veya öğretmen arasında kurulabileceği gruplar tarafindan vurgulanmıştır. Grupların görüşlerini şu şekilde ifade etmişlerdir;

“... sorunun çözümü için rebber ögretmen ve ögretmen işbirlĭ̆i halinde olmahlar...” (OÖÖ1).

"...rebberlik hiæumetinin, idarenin, ögretmenlerin ve ebeveynlerin işbirliği içerisinde çalışmalar yapılırsa daba başarll sonuçlar alınacağına inanıyorum...” (RÖ4).

“...problemleri rebber ögretmenin tek başına çözebileceğini düsünmüyorum. Çözüm için rehber ögrretmen ve okul öncesi ögretmeni işbirliğ yapması gerektiğini düş̈̈nüyorum...” (E4).

Okul öncesi eğitim kurumlarındaki rehberlik kadrosuyla ilgili öneriler içeren görüşler rehber öğretmen ve okul öncesi öğretmenleri tarafından ifade edilmiştir. Bu konuda her iki gruptaki öğretmenler norm kadronun devamlılığı ve arttırılması gerektiğini vurgulamışlardır. Ayrıca fiziksel koşulların iyileştirilmesi önerisi de rehber öğretmenler tarafından ifade edilmiştir. Her iki grubun bu görüşlerine örnek olarak; 
“...anaokullarnda rebberlik kadrosu önce verildi, sonra kaldirld ve tekrar verildi. Yapılan çalısmalarm daha sistematik ve düzenli olması için yetkililer karar vererek bu kadroyu daimi hale getirmeliler...” (RÖ10).

“...bizim okulun 450 mevcudu var ve okulumuzda bir tane rebber ögretmen var. Okulun bütün rebberlĭ̈ine yetismesi çok zor. İkinci bir ögretmenin olması gereklidir diye düşünüyorum..." (OÖÖ7).

“...materyal ibtiyacımı karşılanmalidır ayrica okul öncesi kurumunda bir rehber ögretmen çalışacak ise ona ayr bir oda sağlanmahdir...” (RÖ2).

\section{SONUÇ ve TARTIŞMA}

Bu araştırmada okul öncesi eğitim kurumlarındaki rehberlik hizmetleri paydaşlarından görüşler alınarak rehberliğin derinlemesine incelenmesi amaçlanmıştır. Görüşmelerde katılımcı gruplar okul öncesi eğitim kurumlarında uygulanan rehberlik hizmetlerine yol gösterebilecek önemli görüşler sunmuşlardır. Bu görüşler doğrultusunda ortaya çıkan "rehberlik faaliyetleri” kategorisinde, katılımcı gruplar ebeveyne, öğretmene, çocuğa rehberlik hizmetleri sunulduğu ayrıca sınıf içerisinde de rehberlik faaliyetleri yapıldığını ifade etmişlerdir. Araştırmamızdaki rehberlik hizmetlerinin en çok ebeveynlere yönelik seminerler ve bire bir görüşmeler şeklinde yapıldığına dair bulgularla Akgün (2010) ve Kanak ve diğerleri (2018) tarafindan yapılan araştırmalarda elde edilen ailelere seminer ve bire bir görüşmelerle rehberlik yapıldığına dair bulgular birbirini desteklemektedir. Okul öncesi ve rehber öğretmenleri ebeveynlere yapılan rehberlik hizmetlerinin yanında, çocuklar ve öğretmenler için bire bir görüşmeler veya sınıfta rehberlik faaliyetlerinin yapıldığını da ifade etmişlerdir. Ancak çocuklarla bire bir veya sınıfta düzenlenecek olan rehberlik faaliyetlerinde dikkat edilmesi gereken nokta oyun, drama, çizimler, parmak oyunları ve benzeri etkinliklerin kullanılmasıdır. Bu şekilde düzenlenen rehberlik faaliyetleri daha verimli olur (Pardeck ve Pardeck, 1989; Van Hoose, Peters ve Leonard, 1970). Uzmanların bu önerilerinin çocukların yaşadıkları problemlerin çözümünde nasıl etkili olduğunu araştırmamızın bulgularında görmek mümkündür. Rehber öğretmenlerin ifadelerinden okul öncesi rehberlik hizmetlerinin başarılı olmasında çocuk merkęli rehberliğin önemli bir etken olduğu anlaşılmaktadır. Bu sonuç, çocuk merkezli uygulamalar yapmanın, sınıf uygulamalarından istenilen sonuçları elde etmenin yanında okul öncesi rehberlik hizmetlerinin de başarılı olmasında önemli bir etken olduğunu ortaya koymuştur.

Araştırmamızın diğer bulgularına göre, okul öncesi eğitimde yürütülen rehberlik hizmetlerinin en çok bahsedilen faydası hem ebeveyn hem de öğretmene destek olmasıdır. Bu destek ebeveyn ve öğretmenlerin çocuklarda karşılaştıkları okula uyum, davranış problemleri, korkular, kaynaştırma, arkadaş ilişkileri, akran zorbalığı, dikkat eksikliği, teknoloji bağımlılı̆̆1 konularında olmuştur. Bu 
durum ebeveynlerin ve okul öncesi öğretmenlerinin bu konularla ilgili uzman desteğine ihtiyaç duyduğunu göstermektedir. Ayrıca katılımcı gruplar, rehberlik hizmetlerinin bir diğer faydasını problemlerin çözümü olarak ifade etmişlerdir. Okul öncesi öğretmenlerin ve bu yaş çocuklara sahip ebeveynlerin çocukları ve onların eğitimleriyle ilgili karşılaştıkları sorunlar göz önünde bulundurulduğunda (Başaran, Gökmen ve Akdağ, 2014; Güder, Alabay ve Güner, 2018; İnan, 2010; Sabanc1, Altun ve Altun, 2018) rehberlik servisinin bu konularda destek vermesi ve problemleri çözüme kavuşturmasının hem ebeveynler hem de öğretmenler için önemli olduğu söylenebilir. Çünkü bu problemler okul öncesinde ebeveynlerin çocuklarında karşılaştıkları önemli problemlerdendir ve öğretmenler bu konuda ebeveynlere destek vermede yetersiz olabilmektedir (Tekin, 2012). Özellikle öğretmenlerin rehberlik sayesinde iş yüklerinin azaldığ1 yönündeki bulgu da bu doğrultuda daha anlamlı hâle gelmektedir. Sınıf uygulamalarının etkililiği perspektifinden bakıldığında, öğretmenlerin sınıf içerisindeki çeşitli problemlerle baş etmeye çalışmaları onların eğitsel faaliyetlere ayırdıkları zamanın daha azalmasına ve böylece pedagojik verimin düşmesine sebep olur (Aydın, 2008; Gülşen, 2010). Bu sonuçlar doğrultusunda, okul öncesi dönem rehberliğinin sınıf içi uygulamaların kalitesini arttırmak için önemli bir destek hizmet olduğunu söyleyebiliriz. Çocukların sonraki yaşlarını olumlu etkileyecek olan erken müdahale rehberlik hizmetlerinin diğer bahsedilen faydası olmuştur. $\mathrm{Bu}$ sonuç, katılımcı grupların; rehberlik faaliyetlerinin bu yaş çocuklarının sonraki yaşamlarını olumlu yönde etkileyeceği yönündeki inançlara sahip olduğu anlamına gelebilir. Yapılan araştırmalarda rehber öğretmenlerin rehberliğin erken müdahale sağlama adına önemli olduğu yönündeki görüşlerini içeren sonuçlar (Gençoğlu, Demirtaş-Zorbaz, Demircioğlu ve Ekin, 2019; Kanak ve diğerleri, 2018) araştırmamızın bu bulgusunu desteklemektedir. Rehberliğin en önemli savunularından birisi olan erken müdahale, okul öncesi eğitimin de en önemli amaçlarından birisidir (MEB, 2013). Bu doğrultuda rehberlik hizmetlerinin okul öncesi eğitimin temel amaçlarını güçlendirmek için önemli bir eğitsel destek olduğu söylenebilir.

Yapılan araştırmalarda, okul öncesi rehber öğretmenlerinin mesleki memnuniyetinin ilkokul rehber öğretmenlerine göre daha düşük olduğu yönündeki sonuç (Nas ve diğerleri, 2017) ve okul öncesi rehber öğretmenlerinin düşük mesleki memnuniyete sahip oldukları yönündeki sonuç (Kadıŏlu, 2014), araştırmamızda rehber öğretmenler tarafindan belirtilen "(mesleki açıdan) iyi hissetme" görüşüyle kısmen çeliştiği söylenebilir. Çünkü mevcut araştırmada olumlu mesleki memnuniyetlerini açıcça ifade eden rehber öğretmen sayısının az olmasına rağmen diğer kategorilerde rehberlik hizmetlerinin faydalı olduğunu ve ebeveynler ve öğretmenler için uzman desteği sunarak problemlerine çözüm bulunduğunu ifade etmeleri rehber öğretmenlerin mesleki açıdan yaptıkları işi değerli gördükleri anlamına gelebilir. Diğer taraftan, rehberlik hizmetlerinin 
çocukların kendilerini iyi hissetmeleri açısından da faydalı olduğu yönündeki okul öncesi öğretmenleri görüşü, rehberliğin çocuk/öğrenci mutluluğunu sağlama temel amacinın (Tan, 1992; Yeşilyaprak, 1995) sağlandığını göstermektedir.

Okul öncesi eğitim rehberlik hizmetlerindeki “iş birliğinin”, katılımcı gruplar tarafindan rehberliğin başarılı olmasındaki nedenler, karşılaşılan problemler ve önerilerle ilgili kategorilerde vurgulanması oldukça önemli olduğunu ortaya koymaktadır. Aliyev, Ergüner-Tekinalp, Ülker ve Shine-Edizer (2012) tarafindan yapılan araştırmada ortaya çıkan, rehber öğretmenlerin okul yöneticileri ve okul öncesi öğretmenleriyle işbirliği kuramadıkları yönündeki sonuç; araştırmamızdaki rehber öğretmenin öğretmenlerle, ebeveynlerle işbirliği kurdukları yönündeki sonuçla farklılık göstermektedir. Bu farklılık, son yıllarda okul öncesi eğitim kurumlarındaki rehberlik hizmetlerinin önceki y1llara göre daha önemli olarak görülmesinden veya ebeveynlerin ve öğretmenlerin rehberlik servisinin önemini daha iyi kavramalarından kaynaklanmış olabilir. Zira okul öncesi öğretmenlerinin rehberlik faaliyetlerini önemli olarak değerlendirmeleri ve ailelerin, okul öncesi öğretmenlerinin rehber öğretmenlerle işbirliği yaptıklarına dair araştırma bulguları (Eren, 2014; Kardeş ve Akman, 2014) bizim bu varsayımımızı destekler niteliktedir. Ancak iş birliği kurulmadığı takdirde rehberliğin başarılı olamayacağı, araştırmamızın "karşılaşılan problemler" kategorisindeki ebeveyn ilgisizliğiyle ilgili görüşlerden anlaşılmaktadır. Dolayısıyla okul öncesi eğitimin doğası gereği sınıf içi uygulamalar için önemli olan işbirliğinin rehberlik hizmetleri için de önemli olduğu ve mevcut okul öncesi eğitim programında rehberlikle ilgili ifadelerde bu üç grubun işbirliği içerisinde çalışmalarının neden önemli olduğu araştırmamızın bulgularından anlaşılmaktadır.

Mevcut araştırmada, katılımcı gruplar tarafindan önemle vurgulanan "rehber öğretmenlerin okul öncesi eğitimde rehberlikle ilgili lisans yıllarında eğitim almaya" yönelik önerileri, Aliyev ve diğerleri (2012) tarafından yapılan araştırmada elde edilen bulguyla benzerlik göstermektedir. Araştırmamızın bu bulgusu rehber öğretmenler tarafindan ifade edilen okul öncesi yaş çocuklarıyla iletişim kurmakta zorlandıklarına yönelik görüşleriyle birlikte düşünüldüğünde, rehberlik ve psikolojik danışmanlık lisans eğitiminde okul öncesi dönem rehberlik eğitimine yer verilmesinin önemli bir ihtiyaç olduğu anlaşılmaktadır. Aslında bu ihtiyacın okul öncesi eğitim öğretmenleri için de geçerli olduğunu söyleyebiliriz. Çünkü yapılan araştırmalar okul öncesi öğretmenlerinin rehberlikle ilgili karşılaştıkları problemlerin çözümünde yetersiz kaldıklarını ve rehberlikle ilgili eğitime ihtiyaç duyduklarını tespit etmiştir (Bilgin, 2017; Büyükgöncü, 2013; Çevik, 2017; Kılıçoğlu, 2013; Tekin, 2012). Bu doğrultuda mevcut araştırma hem okul öncesi öğretmenleri hem de rehber öğretmenler için okul öncesinde rehberlikle ilgili daha etkili olabilecek bir eğitim verilmesinin önemli bir ihtiyaç olduğunu diğer araştırmaların sonuçlarını destekleyerek tekrar ortaya çıkarmıştır. Bununla birlikte bu ihtiyacın giderilmesi için okul öncesi eğitim kurumlarında çalışan rehber 
öğretmenler için mesleki bilgilerini arttıracak çağdaş yetişkin eğitimi (androgoji) tekniklerinin benimsendiği profesyonel gelişim çalışmaları düzenlenebilir.

Çocuk merkezli rehberlik ve iş birliği, rehberlik hizmetlerinin başarılı olmasını sağlarken bazı etkenler de başarısını olumsuz yönde etkileyebilir. Araştırmamızın "karşılaşılan problemler" kategorisi altında katılımcı gruplar tarafindan sıralanan etkenler bu bağlamda düşünülebilir. Rehberlik hizmetlerinde karşılaşlan problemlerden biri olan fiziksel koşullar olduğuna dair bulgumuz okul öncesi eğitim sınıflarında yürütülen eğitsel faaliyetlerdeki kalitenin önemli bir unsuru olan fiziksel olanakların bu eğitim kademesindeki rehberlik hizmetleri için de önemli olduğunu göstermiştir. Fiziksel koşulların rehber öğretmenler için önemli bir problem olduğunu tespit eden araştırmalar mevcut araştırmanın bu bulgusuyla örtüşmektedir (Akalın, 2014; Aliyev ve diğerleri, 2012). Ayrıca rehber öğretmenlerin rehberlik hizmetleri için önerileri kategorisinde fiziksel koşulların iyileştirilmesine yönelik ifadeleri bu konunun önemli olduğunu göstermektedir. Karşılaşılan problemlerden olan ebeveyn ilgisizliği, çocuklarla iletişim ve işbirliği diğer bulgularla birlikte tartışılmıştır.

Bu araştırmanın okul öncesinde sunulan rehberlik hizmetlerine okul öncesi öğretmeni, okul rehber öğretmeni ve ebeveyn görüşleri bağlamında ele alıp inceleyerek alan yazınına önemli katkılar sağlayacağı düşünülmektedir. Araştırmanın sonuçları doğrultusunda şu öneriler sunulabilir: Okul öncesi rehberlik programları; okul öncesi öğretmeni, okul rehber öğretmeni, ebeveyn ve okul yöneticileri gibi tüm paydaşların beklenti ve ihtiyaçları iyi analiz edilerek günümüzün eğitim beklentilerine göre yeniden revize edilebilir. Her okul öncesi eğitim kurumunda çocuk sayısına bakılmaksızın en az bir rehber öğretmen kadrosu tahsis edilebilir. Üniversitelerin rehberlik ve psikolojik danışmanlık lisans programlarında okul öncesinde rehberlik uygulamalarına yönelik farklı ders çeşitliliklerine yer verilebilir. Okul öncesi dönemde sunulan rehberlik hizmetlerinin önem ve işlevlerine yönelik bilgilendirici aile eğitim programları düzenlenebilir.

Bu araştırma okul öncesi öğretmeni, okul rehber öğretmeni ve ebeveyn görüşleri esas alınarak ve nitel araştırma deseni kullanılarak gerçekleştirilmiştir. Bundan sonraki benzeri araştırmalarda bu paydaşlara okul yöneticileri de dâhil edilerek ve nitel-nicel karma araştırma desenleri bir arada kullanılarak yapılabilir.

\section{KAYNAKÇA}

Akalın, S. (2014). Okul öncesi eğitim kurumlarında çalışan rehber öğretmenlerin kaynaştırma uygulamalarına ilisskin gereksinimleri. International Journal of Early Childhood Special Education, 6(1), 115-140. 
Akgün, E. (2010). Okul öncesi öğretmenlerinin bakış acısıyla anasınıflarındaki rehberlik hizmetlerinin değerlendirilmesi. İlkögretim Online, 9(2), 474-483.

Aliyev, R., Ergüner-Tekinalp, B., Ülker, R., \& Shine- Edizer, F. (2012). The perceptions of school counselors and principals towards new psychological counseling and guidance services in early childhood education in Turkey. Educational Sciences: Theory \& Practice - Special Issue, Autumn, 3083-3098.

Apps, P., Mendolia, S., \& Walker, I. (2013). The impact of pre-school on adolescents' outcome: Evidence from recent an English cohort. Economics of Education Review, 37, 183-199.

Aral, N. \& Can Yaşar, M. (2014). 36-72 ayllk çocuklar için eğitim programı. Köksal Akyol, A (Ed.). Her yönüyle okul öncesi eğitim içinde (s. 238-272). Ankara: Hedef yayıncılık.

Aydın, A. (2008). Simıfyönetimi. Ankara: Pegem Akademi.

Başaran, S., Gökmen, B., \& Akdă̆, B. (2014). Okul öncesi eğitimde okula uyum sürecinde öğretmenlerin karşılaştığ1 sorunlar ve çözüm önerileri. Uluslararası Türk Ë̆itim Bilimleri Dergisi, 2014(2), 197-223.

Bilgin, H. (2017). Development of a preschool teacher's guidance qualifications scale and its psychometric properties. Journal of Education and Training Studies, 5(9), 83-93.

Büyükgöncü, N. (2013). Okul öncesi eğitim kurumlarnda uygulanan bireyi tanmma tekniklerinin ögretmen görüs̆̈̈ açısından değerlendirilmesi. Yayınlanmamış Yüksek Lisans Tezi, Erciyes Üniversitesi, Kayseri.

Cortazar, A. (2015). Long-term effects of public early childhood education on academic achievement in Chile. Early Childhood Research Quarterly. 32(3). 13-22.

Çevik, G. B. (2017). Examining pre-school teachers' and parents' views on counseling and guidance services in pre-school education. International Journal of Evaluation and Research in Education, 6(3), 207-215.

Erden, M. (1988). Öğretmenlik mesleğine giriş. İstanbul: Alkım Yayınları.

Eren, R. (2014). Milli Eğitim Bakanluğ’na bağh resmi ve bağımsız anaokullarndaki rehberlik ve psikolojik danışma faaliyetlerinin incelenmesi. Yayınlanmamış Yüksek Lisans Tezi, Necmettin Erbakan Üniversitesi, Konya.

Erkan, S. (2011). Okul psikolojik danısma ve rehberlik programlarmm hą̧rlanmasi. Ankara: Pegem Akademi Yayıncilık.

Gencoglu, C., Demirtas-Zorbaz, S., Demircioglu, H., \& Ekin, S. (2019). Psychological counseling and guidance services in early childhood education. Educational Policy Analysis and Strategic Research, 14(1), 6-23.

Gençtanırım-Kurt, D. (2020). Okul öncesi eğitimde kişisel rehberlik. Demicioğlu, H. ve Gençoğlu, C. (Ed.) Okul öncesinde rehberlik içinde (s. 62-81). Ankara: Pegem Yayıncılık. 
Güder, S. Y., Alabay, E., \& Güner, E. (2018). Okul öncesi öğretmenlerinin sınıflarında karşılaştıkları davranış problemleri ve kullandıkları stratejiler. Elementary Education Online, 17(1), 414-430.

Gülşen, C. (2010). Sınıfta zaman yönetimi. Gülşen, C. (Ed.) Kuram ve uygulamada sınıf yönetimi içinde (s. 101-126). Ankara: Anı Yayıncılık.

Heckman, J. J. (2006). Skill formation and the economics of investing in disadvantaged children. Science, 312(5782), 1900-1902.

İnan, H. Z. (2010). Anaokulu çağı çocukları olan anne-babaların karşılaştıkları problemler. Milli Ë̈itim, 188, 218-229.

Kadıoğlu, F. (2014). Psikolojik danısmanlarm (rehber ögretmenlerin) mesleki doyum ile kendine saygular arasindaki ilişkinin incelenmesi. Yayınlanmamış Yüksek Lisans Tezi, Marmara Üniversitesi, İstanbul.

Kagan, S.L., Moore, E., \& Bredekamp, S. (1995). Reconsidering children's early development and learning: Toward common views and vocabulary. National Education Goal Panel.

Kanak, M., Ersoy, M., \& Yerliyurt, N. S. (2018). Okul öncesinde rehberlik hizmetlerinin gerekliliğinin rehber öğretmen görüşleri doğrultusunda değerlendirilmesi. Ekev Akademi, 22, 187-208.

Kardeş, S., \& Akman, B. (2016). The examination of preschool administrators' and preschool teachers' perceptions about counselors' roles. Pegem Journal of Education and Instruction, 6(3), $393-412$.

Kılıçoğlu, E. A. (2013). Okul öncesi eğitimi öğretmenlerinin etkill rebberlike uygulamalarmnn gerçekleștirilmesinde eğitim ibtiyaçlarmm belirlenmesi. Yayımlanmamış Yüksek Lisans Tezi, Selçuk Üniversitesi, Konya.

Kuzgun, Y. (2013). Rebberlik ve psikolojik danısma (12.Bask1), Ankara: Nobel Yayınc1l1k.

Lumeng, J. C., Kaciroti, N., \& Frisvold, D. E. (2010). Changes in body mass index z score over the course of the academic year among children attending Head Start. Academic Pediatrics, 10(3), 179-186.

Mağden, D. \& Şahin, S. (2002). Beş altı yaş grubu çocukların akademik becerilerini değerlendirmeye yönelik pilot bir çalışma. Çocuk Gelişimi ve Ë̆̈timi Dergisi, 1(6-7), 44-60.

Miles, M. B., \& Huberman, M. (1994). Qualitative data analysis (2nd ed.), London: Sage Publication.

Millî Eğitim Bakanlığ1 [MEB], (2006). Okul öncesi eğitim programı (36-72 ayllk cocuklar için). Ankara.

Millî Eğitim Bakanlığ1 [MEB], (2012). Okul öncesi eğitim rehberlik programı. Talim ve Terbiye Kurulu Başkanlığı, Ankara.

Millî Eğitim Bakanlı̆̆1 [MEB], (2013). Okul öncesi eğitim program (36-72 ayllk çocuklar için). Ankara. 
Nas, E., Sak, R., \& Sak, İ. T. S.. (2017). School counselors' job satisfaction: a comparative study of preschool and primary-school counselors in Turkey. International Journal for the Advancement of Counselling, 39(4), 377-394.

Nazlı, S.(2016). Kapsaml gelişimsel rebberlik programı (6.Baskı), Ankara: Anı Yayıncılık.

Özgüven, İ. E. (2001). Çăgdaş eğitimde psikolojïk danısma ve rebberlik, Ankara: PDREM Yayınları.

Patton, M.Q. (2002). Qualitative research and evaluation methods. California: Sage Publications.

Pardeck, J. A., \& Pardeck, J. T. (1989). The elementary school counselor: A role definition. International Journal of Adolescence and Youth, 2(1), 53-60.

Robinson, O.C. (2014). Sampling in interview-based qualitative research: A theoretical and practical guide. Qualitative Research in Psychology, 11(1), 25-41.

Ritchie, J., Lewis, J., Elam, G., Tennant, R., \& Rahim, N. (2014). Designing and selecting samples. J. Ritchie, J. Lewis, C. Mc Naughton Nicholls, \& R. Ormston (Ed.) In Qualitative research practice: A guide for social science students and researchers (p. 111-146). London: Sage.

Sabanc1, A., Altun, M., \& Altun, S. U. (2018). Okul yöneticilerinin, öğretmenlerin ve velilerin görüşlerine göre ana sınıf1 eğitiminde karşılaşılan sorunlar. Kuram ve Uygulamada Eğitim Yönetimi Dergisi, 24(2), 339-385.

Sheridan, S (2007). Dimensions of pedagogical quality in preschool. International Journal of Early Years Education, 15(2), 197-217.

Stabback, P. (2016). What makes a quality curriculum? Current and critical issues in curriculum and learning. UNESCO International Bureau of Education.

Tan, H. (1992). Psikolojik danısma ve rehberlik. Teori ve uygulama. İstanbul: Alkım Yayınları

Tekin, G. (2012). Counseling and guidance services in early childhood education: The case of public preschools in Malatya, Turkey. US- China Education Review (10), 875-880.

The Organization for Economic Co-Operation and Development [OECD] (2017). Starting strong 2017: Key OECD indicators on early childhood education and care, starting strong. Paris: OECD Publishing. 15 Ocak 2020 tarihinde https://read.oecdilibrary.org/education/starting-strong-2017_9789264276116-en\#page9 adresinden erişildi.

Van Hoose, W. H., Peters, M. \& Leonard, G. E. (1970). The elementary school counselor. (2.ed.). USA: Wayne State University Press.

Yerlikaya, İ., Sak, R., \& Şahin Sak, İ. T. (2014). Okul öncesi eğitimde psikolojik danışma ve rehberlik hizmetleri: okul öncesi öğretmen adaylarının ve psikolojik danışman adaylarının görüşleri. Uşak Üniversitesi Sosyal Bilimler Dergisi, 7(2), 286-299.

Yeşilyaprak, B. (1995). "Mesleki gelisim sürecinin basslanguc olarak okul öncesi eğitim”. 10. YA-PA Okul Öncesi Eğitimi ve Yaygznlaștorlması Semineri Kitabı. İstanbul: YA-PA Yayınları. 
Yeşilyaprak, B. (2019). Eğitimde rehberlik hiæ̌metleri (29.bask1). Ankara: Nobel Yayınları.

Yıldırım, A. \& Şimşek, H. (2016). Sosyal bilimlerde nitel araştırma yöntemleri (10.Baskı). Ankara: Seçkin yayıncilik. 